between 10 and 19, depending on the rankings used. To help make that happen, he announced that his coalition government was "inviting proposals" for "a new type of university" that would focus on science and postgraduates. But there was a catch. "There will," Willetts stated, "be no additional government funding." This triggered a storm of protest from experts and several (poor) impressions of Cruise.

During his speech, Willetts was keen to reference plans for a huge university campus in New York being pushed forward by Cornell University (see Nature http://doi.org/hj9;2011). And private higher education is clearly on the rise, albeit probably more in teaching than the research arena. But, as critics quickly pointed out, the Cornell project is receiving at least US\$100 million in public funding.

Experts contacted by Nature said that the idea that private finance and business sponsorship alone can create a new institution - as Willetts suggested - seems fanciful. "I don't think this is likely to fly without very, very substantial amounts of new money," says Paul Nightingale, a science and technology policy expert at the University of Sussex in Brighton, UK. And Roger Geiger, who studies research universities at Pennsylvania State University in University Park, says: "Industry has its own research labs and if they're going to invest their own money, that's where they're going to put it."

Neither Willetts nor his Department for Business, Innovation and Skills was willing to elaborate on the plans this week, saying only that much depends on the proposals that the department receives. The government insists that there has been "a lot of interest", but without government incentive, will that interest go any further?

In his speech, given just a stone's throw from the Houses of
Parliament, Willetts also highlighted the good that his government has done. As the United Kingdom stumbles through one of the worst economic climates in living memory, the fact that the country's research budget has been largely protected from the severe cuts inflicted on other public sectors (including university teaching) is something to be thankful for.

And it is a shame that Willetts' high-profile but extremely brief mention of the universities idea distracted from other points in the speech, such as an admission that the government is involved in "picking winners" - investing in technologies under-

"Private higher pinned by science and research that could education is clearly on the rise, albeit probably more in teaching than the research arena." bring economic benefit - something that politicians have been reluctant to acknowledge previously.

"The noises are positive. Every time he speaks about science and innovation the thinking seems to get a little more sophisticated," says Kieron Flanagan, a lecturer in science and technology policy at the University of Manchester, UK. This is a welcome shift from previous Conservative policies, which tended towards generic initiatives. However, the rhetoric has yet to be matched with much action, Flanagan says, although increased efforts to link businesses and research in key areas are a good start.

Many will be happy to be proved wrong if a number of world-leading finance-free universities do arise in the United Kingdom, as Willetts hopes. Meanwhile, discussion of the idea certainly has one thing in its favour: it's not costing anything.

\section{Whales for sale}

\section{A quota-trading scheme could end conflict between whalers and conservationists.}

$\mathrm{I}$ n the chilly waters of the Southern Ocean, an annual drama is under way once more. The Japanese whaling fleet has set to sea again. So has a flotilla of vessels crewed by conservationists and activists, determined to keep the hunters from their prey.

Three Australian anti-whaling campaigners boarded the Shonan Maru No. 2 whaling ship on Sunday. After negotiations, the Japanese government has agreed to release them to an Australian customs ship. The incident came just days after the conservation ship Brigitte Bardot was smashed by a giant wave and seriously damaged while pursuing the ship Nisshin Maru, some 2,400 kilometres from the Australian coast. Sea Shepherd Conservation Society, a group based in Friday Harbour, Washington, that operates the stricken vessel, is counting the cost of its principles. This isn't the first time: in January 2010, the group's powerboat Ady Gil sank after a collision with the Shonan Maru No. 2. The skirmishes and confrontations continue, with campaigners maintaining their high-risk pursuit and their attempts to foul the propellers of the whaling ships with ropes, and the whalers responding with water cannon. Surely there is a better way?

Perhaps. On page 139 of this issue, three environmental scientists outline a plan to introduce tradable quotas for whale catches. Under the scheme, conservationists could buy (and retire) the quotas from whalers, giving industry a way to profit from the animals without killing them. In return, anti-whaling campaigners could be more certain that their actions were reducing the slaughter. Theoretically, such a scheme would allow both sides to benefit with no loss of face. As the researchers say, it could "open the door to reducing mortality without needing to battle over whether whaling is honourable or shameful". And both the number of whales killed and the associated costs would go down.
The article's authors - Christopher Costello and Steven Gaines of the University of California, Santa Barbara, and Leah Gerber of Arizona State University in Tempe - use the per-animal profit of whaling ships to decide that about US $\$ 13,000$ would be a fair price to buy the life of a minke whale, and $\$ 85,000$ should secure a fin whale. "Whale prices should therefore be within reach of conservation groups and even some individuals," they suggest.

The idea first surfaced in 1982, to little effect. But perhaps, three decades on, its time has come. Market approaches to environmental problems are now common, with carbon offsets bought by individuals to neutralize their greenhouse-gas emissions. Such systems have even been shown to be effective, reducing sulphur dioxide pollution from US power plants.

To put a price on the head of a whale would be a different matter, of course. Committed anti-whaling campaigners would have to put aside moral objections and accept such a scheme's tacit legitimation of whaling as an enterprise to be rewarded, as well as the de facto official approval for the heavily disputed notion that whales (and other animals) are a resource to be exploited. Pro-whaling nations would need to be persuaded that the scheme would have more strategic benefit than their continuing political efforts to lift, or find ways to work around, the current commercial whaling moratorium. Then there is the need for scrutiny and verification of the quota market, not to mention getting such a plan through the political quagmire that bogs down annual meetings of the International Whaling Commission, the body that would be best placed to put a market mechanism into action. (And what of the world's scientists, denied information from some of the 1,000 or so whales slaughtered each year for 'scientific purposes'? Nature suspects that they would manage.)

Still, with political will and goodwill, the idea could work. At the very least, it deserves proper consideration from all involved. As $\rightarrow$ NATURE.COM To comment online, click on Editorials at: go.nature.com/xhunqu events in the Southern Ocean show, pro- and anti-whaling groups will both go to extraordinary lengths to pursue their agendas. To those in peril on the sea, the middle ground should seem just as secure as the moral high ground. 